\title{
Pengaruh Pemberian Salep Kolagen Hidrolisat Ikan Sebagai Penyembuhan Luka Bakar Derajat IIB Berdasarkan Ekspresi Fibroblast Growth Factor 2 (FGF-2) dan Fibroblas pada Tikus Putih (Rattus norvegicus)
}

\author{
The Effect of Hydrolyzed Fish Collagen Ointment to Healing \\ Burns Level IIB by Fibroblast Growth Factor 2 (FGF-2) and \\ Fibroblast \\ in Rats (Rattus norvegicus)
}

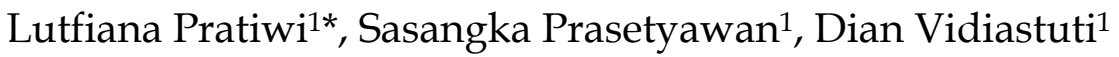

${ }^{1}$ Progam Studi Kedokteran Hewan, Fakultas Kedokteran Hewan Universitas Brawijaya

*email: lutfianapratiwy@gmail.com

\begin{abstract}
ABSTRAK
Luka bakar derajat IIB merupakan kondisi hilangnya jaringan akibat paparan panas meliputi seluruh epidermis dan sebagian dermis. Obat gold standart yang yang sering digunakan adalah Silver sulfadiazine yang relatif mahal dan bersifat toksik dalam jangka waktu lama sehingga diperlukan alternatif pengobatan dari bahan alami seperti kolagen hidrolisat bersumber dari ikan. Kolagen hidrolisat ikan bekerja dengan menarik sel imunitas yaitu makrofag yang akan memproduksi growth factor sehingga mampu mempercepat kesembuhan luka. Penelitian ini menggunakan rancangan RAL dengan sampel 24 ekor tikus putih jantan dengan berat badan 150-200g umur 8-12 minggu yang dibagi 4 kelompok yaitu kontrol positif, dan kelompok terapi kolagen hidrolisat ikan konsentrasi 5\%, 7,5\%, 10\% yang diterapi dua kali sehari selama 10 hari. Hasil dari penelitian menunjukkan bahwa konsentrasi salep kolagen hidrolisat ikan 10\% adalah konsentrasi terbaik dari semua kelompok terapi yaitu mampu meningkatkan ekspresi FGF-2 (36.65 \pm 1.24$)$ \% serta mampu meningkatkan jumlah fibroblas $(40.06 \pm 1.24)$ sel dalam fase kesembuhan luka. Namun kedua hasil yang diperoleh dari konsentrasi salep kolagen hidrolisat $10 \%$ masih kurang efektif dibandingkan dengan obat Silver Sulvadiazine dalam meningkatkan ekspresi FGF-2 (41.69 \pm 0.95$) \%$ dan meningkatkan jumlah fibroblas $(46.50 \pm 1.66)$ sel. Hasil penelitian menunjukkan bahwa salep kolagen hidrolisat ikan dapat digunakan namun masih kurang efektif dikarenakan kedua obat terapi memiliki mekanisme kerja yang berbeda.
\end{abstract}


Kata Kunci: Penyembuhan luka bakar derajat IIB, kolagen hidrolisat ikan, FGF-2, fibroblas

\begin{abstract}
Burns level IIB are a condition of tissue loss due to exposure to heat covering the entire epidermis and part of the dermis. The most commonly used gold standard drug (Silver sulfadiazine) is expensive coast and toxic in the long term that an alternative treatment of natural resources such as hydrolyzed collagen sourced from fish. Hydrolyzed fish collagen act by attracting immune cells such as macrophages that will produce growth factor to accelerate wound healing. This experimental study by ANOVA with 24 samples of 8-12 weeks old male rats (Rattus norvegicus) weight 150-200g divided into 4 groups as positive control, and therapy group based of hydrolyzed fish collagen concentration fish 5\%,7,5\%,10\% which were treated twice a day for 10 days. The results of the study showed that the concentration of $10 \%$ hydrolyzed fish collagen ointment was the best concentration of all therapy groups that was able to increase the expression of FGF-2 $(36.65 \pm 1.24) \%$ and was able to increase the number of fibroblasts $(40.06 \pm 1.24)$ in the wound healing phase. However, both results obtained from the $10 \%$ hydrolized fish collagen ointment concentration were less effective than Silver Sulvadiazine ointment, showed by the increasing of the FGF-2 expression ( $41.69 \pm 0.95) \%$ and increasing of fibroblasts $(46.50 \pm 1.66)$. The results showed that collagen can be used but still less effective because of the difference of mechanism of action between the two drugs.
\end{abstract}

Keywords: Healing burns level IIB , hydrolyzed fish collagen, FGF-2, fibroblast

\section{PENDAHULUAN}

Luka bakar merupakan suatu bentuk kerusakan atau kehilangan jaringan yang disebabkan adanya kontak langsung dengan sumber panas, paparan listrik, zat kimia, maupun radiasi (Rahayuningsih, 2012). Menurut Sarimin (2009), luka bakar derajat kedua paling banyak ditemukan dengan jumlah 36 kasus atau $46,7 \%$ dari seluruh kasus luka bakar yang didapatkan. Luka bakar derajat IIB mengalami kerusakan pada seluruh lapisan epidermis dan $1 / 2$ sampai $7 / 8$ lapisan dermis dengan kelenjar sebasea, dan kelenjar keringat, serta folikel rambut mudah lepas (Kamolz et al., 2012).

Obat topikal yang menjadi gold standart pengobatan luka bakar derajat IIB di pasaran yaitu Silver sulfadiazine. Menurut Fuadi (2015) Silver sulfadiazine bersifat antibakteri serta mampu menarik sel imunitas untuk menghasilkan sitokin dan growth factor dalam mempercepat proses kesembuhan luka. Namun beberapa efek obat tersebut telah dilaporkan selain harga yang relatif mahal, tidak 
dapat diberikan dalam jangka panjang karena dapat bersifat toksik pada luka (Hosseinimehr et al., 2010).

Alternatif pengobatan luka bakar bahan alam yaitu kolagen hidrolisat yang bersumber dari ekosistem perairan (marine colagen) yaitu ikan(Mothumari, 2017). Kolagen hidrolisat merupakan hasil dari proses denaturasi kolagen yang bersumber dari tulang, kulit maupun jaringan pada ikan, sapi, maupun babi (Sibilia et al., 2015). Menurut Yamamoto et al. (2014) kolagen ikan memiliki biokompatibilitas yang baik, sifat antigenik yang rendah, dan biodegradability.

Menurut Isofrah dkk. (2012), pengobatan luka bakar secara topikal lebih efektif karena obat akan mudah diserap kulit dan fungsinya dalam melembabkan bertahan lebih lama. Berdasarkan uraian tersebut, maka perlu dilakukan penelitian mengenai pemanfaatan salep kolagen hidrolisat ikan dalam kesembuhan luka bakar dilihat dari adanya ekspresi Fibroblast Growth Factor 2 (FGF-2) dan peningkatan jumlah fibroblas pada hewan model tikus putih (Rattus norvegicus)

\section{BAHAN DAN METODE \\ Bahan dan alat}

Bahan yang digunakan dalam penelitian ini antara lain kolagen hidrolisat ikan (PEPTIPLUS ${ }^{\circledR}$ XF), Silver sulfadiazine, tikus putih (Rattus norvegicus), pakan minum tikus, normal saline (NS) 0,9\%, ketamin, xylazine, vaselin album, buffer formalin 10\%, aquadest proinjection, aquades, alkohol $70 \%$, etanol 70\%, 80\%, 90\%, 95\%, PBS, larutan xylol, antibodi primer FGF2, antibodi sekunder, Diamano benzidine, pewarna hematoxilin-eosin, asam asetat $(\mathrm{CH} 3 \mathrm{COOH}) 9 \%$.

Peralatan yang digunakan dalam penelitian ini yaitu kandang tikus, underpad, pembatas kandang, waterbath, objek gelas, pinset anatomis, cawan petri, sentrifus, penangas air, timbangan digital, termometer raksa, plat besi ukuran $2 \times 4 \mathrm{~cm}^{2}$, pensil, mikropipet, mikrotube, oven, gloove, masker, pot salep $60 \mathrm{~g}$, kassa, tisu, spatula, plastik bening, gelas ukur, cawan porselen, lumpang, spuit 1cc dan 3cc, seperangkat alat bedah, papan bedah, pot organ, cover glass, blender, Mikroskop $\left(\mathrm{BX} 51^{\circledR}\right)$.

Plat besi ditempelkan menggunakan pinset anatomis pada punggung tikus selama 15 detik tanpa ada tekanan, besi diangkat dan dikompres dengan kasa yang telah dicelupkan ke dalam larutan NS untuk menghentikan perluasan luka di jaringan sekitar.

\section{Metode}

\section{Pembuatan Luka Bakar Derajat IIB}

Metode induksi luka bakar yang digunakan merupakan modifikasi dari penelitian Akhoondinasab et al. (2014) yaitu plat besi ukuran $2 \times 4 \mathrm{~cm}^{2}$ dengan ketebalan $2 \mathrm{~mm}$ dipanaskan dalam air mendidih suhu $100^{\circ} \mathrm{C}$ selama 15 menit dan ditempelkan pada bagian punggung tikus. 


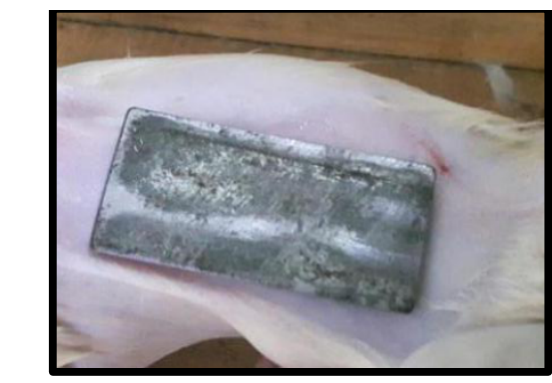

Gambar 1. Penempelan plat besi pada punggung tikus tanpa tekanan

\section{Pembuatan Hidrolisat Kolagen Ikan}

Kolagen hidrolisat ikan didapatkan dalam produk jadi berbentuk serbuk dengan berat $500 \mathrm{~g}$ setiap kemasan. Produk tersebut memiliki merk dagang PEPTIPLUS ${ }^{\circledR} \quad$ XF yang telah mendapat sertifikat uji kandungan.

\section{Pembuatan Salep Kolagen Hidrolisat Ikan}

Proses pembuatan salep diawali dengan menimbang semua bahan yang diperlukan sesuai formula perhitungan salep kolagen hidrolisat ikan (Lampiran 5). Vaselin album dimasukkan ke dalam gelas ukur lalu dileburkan diatas waterbath dengan suhu $50^{\circ} \mathrm{C}$ selama kurang lebih 15 menit. Setelah meleleh, hasil leburan dimasukkan dalam cawan porselen dan digerus hingga homogen dan dingin. Serbuk kolagen hidrolisat ikan ditambahkan sedikit demi sedikit sambil digerus hingga homogen dan menjadi sediaan setengah padat. Sediaan ditimbang seberat $60 \mathrm{~g}$ dan dimasukkan dalam dalam pot salep.

\begin{tabular}{|c|c|c|c|c|}
\hline No & Nama bahan & $\begin{array}{l}5 \\
0 \%\end{array}$ & $\begin{array}{l}7,5 \\
\%\end{array}$ & $\begin{array}{l}10 \\
\%\end{array}$ \\
\hline 1 & $\begin{array}{l}\text { Kolagen } \\
\text { hidrolisat } \\
\text { ikan (g) }\end{array}$ & 3 & 4,5 & 6 \\
\hline 2 & $\begin{array}{l}\text { Vaselin } \\
\text { album (g) }\end{array}$ & $\begin{array}{l}\text { ad } \\
d \\
60\end{array}$ & $\begin{array}{l}\text { add } \\
60\end{array}$ & $\begin{array}{l}\text { ad } \\
d \\
60\end{array}$ \\
\hline
\end{tabular}

Salep hidrolisat kolagen ikan dibuat dengan memformulasikan serbuk hidrolisat kolagen ikan (PEPTIPLUS ${ }^{\circledR}$ XF) dengan bahan pembawa vaselin album konsentrasi 5\%, 7,5\%, 10\% yang dibuat sebanyak 60 gram.

\section{Terapi Salep Kolagen Hidrolisat Ikan}

Pemberian salep kolagen hidrolisat ikan pada tikus dengan luka bakar derajat IIB sebanyak 0,5 g yang diberikan dua sekali sehari (kelompok terapi) selama 10 hari.

\section{Euthanasi dan Isolasi Kulit}

Tikus putih jantan dieutanasi pada hari ke-18 dengan cara dislokasio cervicalis, kemudian diletakkan di atas papan bedah dan dalam posisi dorsal. Daerah kulit yang akan diambil dibersihkan dulu dari rambut yang mulai tumbuh kembali dengan pencukur dan sampel kulit diangkat menggunakan scalpel blade dengan luas $\pm 2 \times 4 \mathrm{~cm}^{2}$ dan sedikit mengikutkan jaringan normal di sekitarnya. Sampel kulit dicuci menggunakan NS kemudian dimasukkan dalam larutan buffer 
formalin $10 \%$ dan disimpan dalam suhu ruang.

\section{Prosedur Pembuatan Preparat dan Pewarnaan Immunohistokimia}

Persiapan reparat yang akan digunakan dalam pewarnaan IHK. Deparafinisasi dilakukan dengan pemberian xylol I, II, dan III masing-masing selama 5 menit.

Rehidrasi dengan memberikan etanol absolut, etanol bertingkat yaitu $95 \%, 90 \%, 80 \%, 70 \%$, aquadest masing-masing selama 5 menit. Blocking endogenous peroxidase dilakukan dengan memberikan $\mathrm{H} 2 \mathrm{O} 2$ dalam aquades selama 10 menit. Preparat dicuci dengan PBS sebanyak 3x masing-masing 5 menit. Pemberian superblok selama 10 menit. Proses pencucian sebanyak $3 x$ masing-masing 5 menit menggunakan PBS.

Antibodi primer FGF-2 1:1000 diinkubasi pada suhu kamar selama semalam. Pencucian menggunakan PBS sebanyak $3 x$ masing-masing 5 menit. Antibodi sekunder rabbit anti rat igG berlabel biotin diinkubasi dengan selama satu jam dengan suhu ruang. Pencucian kembali dengan PBS $\mathrm{pH}$ 7,4 selama 5 menit 3kali. Inkubasi dengan HRP dilakukan pada suhu kamar selama 10 menit. Pencucian kembali menggunakan PBS sebanyak $3 x$ masing-masing 5 menit. Penambahan DAB+substrate dengan microtube ditutupi alumunium foil pada suhu kamar selama 10 menit dan hindari paparan cahaya. Slide preparat dimasukkan dalam aquades.
Prosedur Pembuatan Preparat dan Pewarnaan Histopatologi

Proses fiksasi dilakukan dengan pemberian formaldehyde $10 \%$. Dehidrasi menggunakan etanol bertingkat dari konsentrasi rendah ke konsentrasi tinggi $(70 \%$, $80 \%, 90 \%, 95 \%$ ). Clearing dilakukan dengan penambahan xylol I, II, dan III.

Proses embedding menggunakan parafin cair. Blocking dilakukan dengan menggunakan cetakan sesuai dengan ukuran jaringan.

Pemotongan jaringan menggunakan mikrotom. Deparafinisasi dengan penambahan xylol dua kali selama 5 menit. Dehridasi dengan etanol absolut sebanyak 3 kali dan etanol bertingkat $(95 \%, \quad 90 \%, 80 \%, 70 \%)$ masing-masing 5 menit. Slide direndam di dalam aquades. Pewarnaan slide menggunakan eosin selama 5 menit lalu direndam

dalam aquades. Slide dimasukkan kedalam etanol betingkat (70\%, $80 \%, 90 \%, 95 \%)$ masing-masing selama 10 menit. Perendaman kedalam etanol absolut selama 5 menit sebanyak 3 kali. Slide dimasukkan dalam xylol selama 5 menit sebanyak 2 kali dan dikeringkan. Proses mounting menggunakan ettelan dan ditutup cover glass. Pengamatan slide dibawah mikroskop cahaya.

\section{HASIL DAN PEMBAHASAN}




\section{Gambaran makroskopik}

Berdasarkan hasil gambaran makroskopik kesembuhan luka yang diambil pada hari ke-10 pasca induksi luka bakar derajat IIB menunjukkan bahwa kelompok $\mathrm{K}+$ mengalami penyembuhan yang paling baik dibandingkan dengan kelompok perlakuan. Perlakuan K+ yang diterapi Silver sulfadiazine menunjukkan luas perlukaan yang semakin mengecil, mengering dan keropeng terlepas, serta adanya pertumbuhan rambut di area luka yang menandakan adanya perbaikan folikel rambut pada lapisan dermis (Gambar 2).

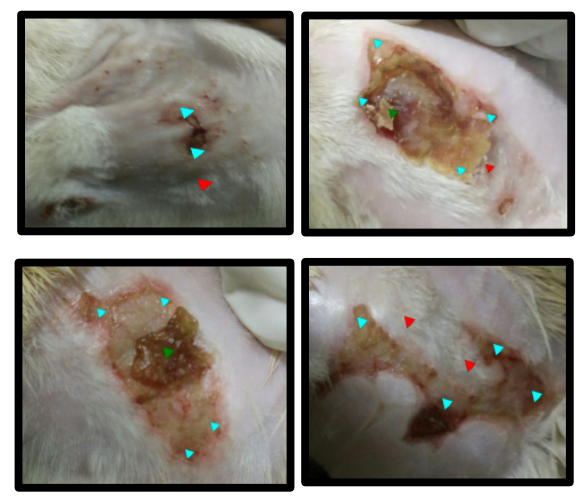

Gambar 2 Gambaran makroskopis perkembangan kesembuhan jaringan kulit tikus pada hari ke-10 pasca induksi luka bakar derajat IIB pada semua kelompok ( area yang masih mengalami luka), (- pertumbuhan rambut area luka)

Berdasarkan hasil gambaran makroskopik kesembuhan luka yang diambil pada hari ke-10 pasca induksi luka bakar derajat IIB menunjukkan bahwa kelompok $\mathrm{K}+$ mengalami penyembuhan yang paling baik dibandingkan dengan kelompok perlakuan. Pemberian Silver sulfadiazine berpengaruh lebih baik yang dapat membantu mengurangi adanya infeksi dan menginduksi sel-sel imunitas sehingga mempercepat proses penyembuhan luka. Berdasarkan hasil tersebut diduga bahwa pada luka bakar terjadi infeksi sekunder dimana terapi salep kolagen hidolisat ikan belum mampu mengurangi resiko infeksi tersebut, karena tidak memiliki kandungan antibiotik didalamnya.

Kelompok P2 pasca induksi luka bakar derajat IIB diterapi menggunakan salep kolagen hidrolisat ikan 7,5\% menunjukkan bahwa luas perlukaan pada kulit sudah mulai mengecil yaitu setengah dari luka pasca induksi pertama (Gambar 5.1 C). Kelompok P2 menunjukkan kesembuhan luka yang lebih baik dibandingkan dengan P1 namun kurang baik dibandingkan dengan $\mathrm{K}+$. Kelompok P3 menunjukkan kesembuhan luka yang lebih baik dibandingkan dengan P1 dan P2 namun masih kurang baik dibandingkan dengan $\mathrm{K}+$. Pada kelompok P3, keropeng pada area luka sudah terlepas dan permukaan area luka sudah mulai mengecil atau berkurang, hal ini ditunjukkan dengan adanya kondisi luka yang sudah menutup sempurna dengan adanya pertumbuhan rambut (Gambar 5.1 D). Hal ini sesuai dengan pendapat Latifa (2017) bahwa konsentrasi 10\% adalah konsentrasi terbaik yang mampu mempercepat penutupan luka. 
5.1 Efek Pemberian Salep Kolagen Hidrolisat Ikan pada Tikus Pasca Luka Bakar Derajat IIB terhadap Ekspresi Fibroblast Growth Factor 2 (FGF-2)

Fibroblast Growth Factor 2 (FGF-2) diproduksi oleh platelet dan makrofag untuk menarik leukosit pada fase inflamasi, dan diproduksi oleh sel fibroblas pada fase proliferatif dan berlanjut pada sintesis kolagen

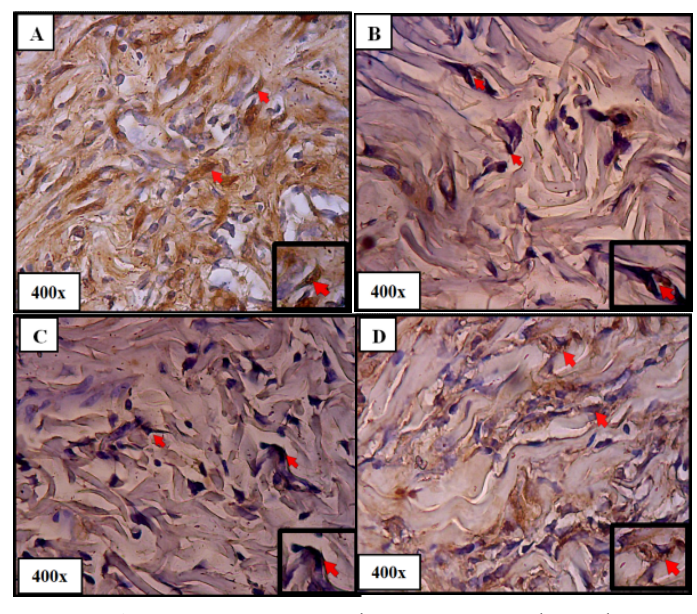

Gambar 3 Gambaran mikroskopis ekspresi FGF-2 pada jaringan dermis kulit tikus metode immunohistokimia (400x)

(A) Kontrol positif (B) terapi salep kolagen hidrolisat ikan5\% (C) terapi salep kolagen hidrolisat ikan 7,5\% (D) terapi kolagen hidrolisat kolagen ikan 10\% ( menunjukkan ekspresi FGF-2)

Tabel 2 Ekspresi FGF-2

\begin{tabular}{lc}
\multicolumn{1}{c}{ Kelompok } & $\begin{array}{c}\text { Rata-rata } \\
\text { Ekspresi FGF- } \\
\text { 2 } \pm \text { SD (\%) }\end{array}$ \\
\hline K+(Kontrol positif) & $41.69 \pm 0.95^{\mathrm{c}}$ \\
\hline $\begin{array}{l}\text { P1(Terapi salep } \\
\text { hidrolisat kolagen } \\
\text { ikan 5\%) }\end{array}$ & $24.75 \pm 2.86^{\mathrm{a}}$ \\
\hline $\begin{array}{l}\text { P2(Terapi salep } \\
\text { hidrolisat kolagen } \\
\text { ikan 7,5\%) }\end{array}$ & $28.37 \pm 1.78^{\mathrm{a}}$ \\
\hline $\begin{array}{l}\text { P3(Terapi salep } \\
\text { hidrolisat kolagen }\end{array}$ & $36.65 \pm 1.24^{\mathrm{b}}$ \\
\end{tabular}

$$
\begin{aligned}
& \text { Keterangan : Perbedaan notasi menunjukkan } \\
& \text { adanya perbedaan signifikan } \\
& (\mathrm{P}<0.05) \text { antar kelompok }
\end{aligned}
$$

Pada hari kesepuluh termasuk dalam puncak proliferasi fibroblas, dimana fibroblas akan mengekspresikan FGF-2 sehingga FGF-2 jumlahnya meningkat. Berdasarkan penelitian Fuadi dkk. (2015) Silver sulfadiazine bersifat sebagai antibakteri serta mampu merangsang sel-sel seperti makrofag untuk menghasilkan growth factor dan sitokin seperti TGF- $\beta$, EGF, IL1 dan lainnya sehingga mendukung proses penyembuhan luka.

Rata-rata ekspresi kelompok P3 (36.65 \pm 1.24$) \%$ menunjukkan persentasi yang lebih rendah secara signifikan $\quad(\mathrm{P}<0.05) \quad$ terhadap $\mathrm{K}+(41.69 \pm 0.95) \% \quad$ (Tabel 5.1). Perbedaan signifikan kelompok P3 dan $\mathrm{K}+$ menunjukkan bahwa penggunaan salep hidrolisat kolagen $10 \%$ masih kurang efektif dibandingkan dengan penggunaan obat Silver sulfadiazine.

Pada penelitian Paddle et al. (2008) efek toksis silver pada luka bakar yaitu menggangu proses sintesis pada fibroblas dan keratinosit. Namun penggunaan hingga mencapai toksik membutuhkan waktu cukup lama yang dibuktikan dengan penelitian Bidgoli et al. (2013) pemberian nanopartikel silver pada terapi 21 hari pasca luka bakar tidak menunjukkan gejala abnormal pada luka serta hasil pengujian beberapa organ ginjal, liver, spleen, dan lainnya tidak 
Tabel.3 Jumlah Fibroblas

mengalami kelainan. Hal ini menunjukkan untuk mencapai konsentrasi toksik yaitu dengan pemberian silver diatas terapi 21 hari pasca luka bakar.

\subsection{Efek Pemberian Salep} Hidrolisat Kolagen Ikan pada Tikus Pasca Luka Bakar Derajat IIB terhadap Jumlah Fibroblas

Hasil perhitungan fibroblas dilakukan dengan metode histopatologi pengecatan hematoxylin eosin. Fibroblas memiliki karakteristik ukuran yang cukup besar, inti berbentuk elips yang terwarnai ungu, memiliki sitoplasma yang terwarnai merah, serta kedua ujung sel berbentuk lancip (Gambar 5.3)
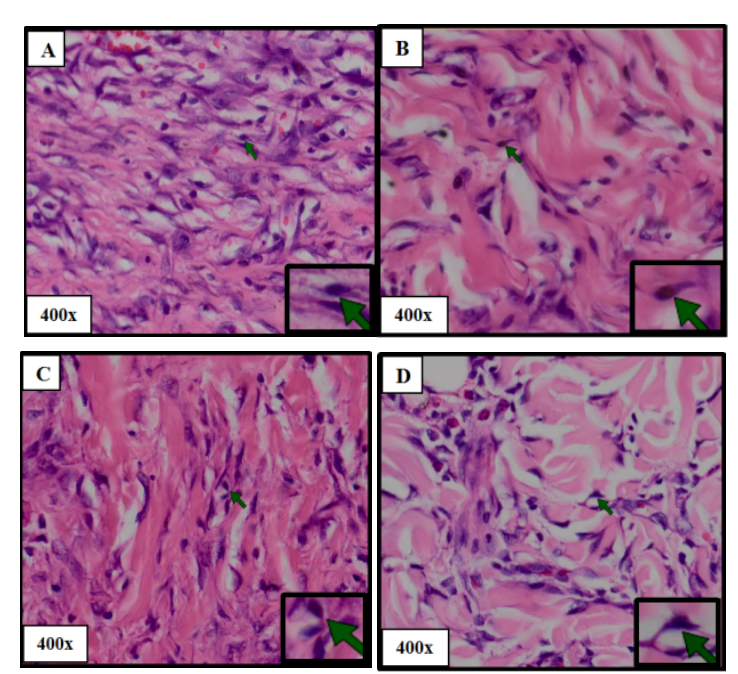

Gambar 5.3 Gambaran mikroskopis jumlah sel fibroblas jaringan kulit tikus dengan pengecatan hematoxylin eosin perbesaran (400x)

Keterangan: (A) Kontrol positif (B) terapi salep hidrolisat kolagen ikan 5\% (C) terapi salep kolagen hidrolisat ikan 7,5\% (D) terapi kolagen hidrolisat kolagen ikan $10 \%$ ( menunjukkan sel fibroblas)

\begin{tabular}{lc}
\hline \multicolumn{1}{c}{ Kelompok } & $\begin{array}{c}\text { Jumlah } \\
\text { Fibroblas } \\
\text { Rata- } \\
\text { rata } \pm \text { SD(sel) }\end{array}$ \\
\hline $\begin{array}{l}\text { K+ (Kontrol } \\
\text { positif) } \text { Tabel.3 Jumlah Fibroblas }\end{array}$ & $\begin{array}{c}46.50 \pm 1.66^{\mathrm{d}} \\
\text { P1 (Terapi salep } \\
\text { hidrolisat kolagen } \\
\text { ikan 5\%) }\end{array}$ \\
\hline $\begin{array}{l}\text { P2 (Terapi salep } \\
\text { hidrolisat kolagen } \\
\text { ikan 7,5\%) }\end{array}$ & $32.56 \pm 0.86^{\mathrm{a}}$ \\
\hline $\begin{array}{l}\text { P3 (Terapi salep } \\
\text { hidrolisat kolagen }\end{array}$ & \\
ikan 10\%) & \\
\hline \multicolumn{2}{l}{$\begin{array}{l}\text { Keterangan: } \\
\text { menunjukkan } \\
\text { signifikan (P<0.05) antar kelompok }\end{array}$} \\
\hline
\end{tabular}

Berdasarkan Tabel 5.2 rata-rata jumlah fibroblas pada $\mathrm{K}+$

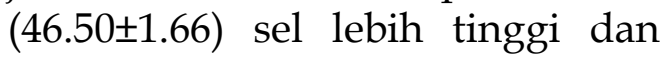
berbeda signifikan $\quad(\mathrm{P}<0.05)$ dibandingkan semua kelompok terapi. Hal ini menunjukkan proliferasi fibroblas serta migrasi fibroblas ke area luka berjalan dengan baik dalam proses perbaikan jaringan. $\mathrm{K}+$ merupakan kelompok yang diberikan terapi obat Silver sulfadiazine yang merupakan gold standart dalam mengobatan luka bakar derajat II maupun III. Obat tersebut mengandung agen antibakteri yaitu golongan sulfonamid yang dapat menekan adanya infeksi bakteri pada luka. Menurut Fuadi dkk (2015) Silver sulfadiazine merupakan obat antibakteri golongan sulfonamid dengan mekanisme berkompetisi dengan substrat PABA untuk sintesis enzim dihidropetroat sehingga 
mencegah sintesis asam folat bakteri. Perbedaan mekanisme kedua bahan terapi tersebut mengakibatkan proses kesembuhan luka yang terjadi antara kelompok kontrol dan terapi berbeda. Luka bakar merupakan tempat yang ideal untuk pertumbuhan bakteri karena luka tersebut cenderung memiliki perlukaan yang luas dan kondisi yang cenderung basah (Nugraha et al., 2011). Selain hal tersebut keberadaan bakteri dapat dipicu dari kedalaman luka bakar seta ketidakseimbangan flora normal pada kulit akibat paparan luka bakar. Menurut Khazaeli et al. (2014) tikus putih memiliki luas permukaan kulit $377,2 \mathrm{~cm}^{2}$ dengan ketebalan kulit 1-1,6 mm untuk luka bakar derajat IIB.

\section{KESIMPULAN}

Berdasarkan hasil penelitian yang telah dilakukan dapat disimpulkan bahwa

1. Salep kolagen hidrolisat ikan $10 \%$ pada tikus putih (Rattus norvegicus) dengan luka bakar derajat IIB merupakan konsentrasi terbaik dibandingkan konsentrasi 5\% dan $7,5 \%$ yang dapat meningkatkan ekspresi FGF-2 $(36.65 \pm 1.24) \%$

2. Terapi salep kolagen hidrolisat ikan konsentrasi $10 \%$ pada tikus putih (Rattus norvegicus) dengan luka bakar derajat IIB merupakan konsentrasi terbaik dibandingkan konsentrasi 5\% dan $7,5 \%$ yang dapat meningkatkan jumlah fibroblas sebesar (40.06 \pm 1.24$)$ sel

Saran untuk penelitian lanjutan yaitu meningkatkan konsentrasi salep di atas $10 \%$ serta menambahkan antibakteri dalam salep kolagen hidrolisat ikan

\section{DAFTAR PUSTAKA}

ABA. 2014. American Burn Association: National Burn Repository Report of Data from 2003-2012. National Burn Repository. America.

Adinda, D. 2017. Pengaruh Pemberian Gel Ekstrak Teh Hijau (Camellia sinensis) Terhadap Ekspresi IGF-1 dan Gambaran Histopatologi Epidermis pada Tikus (Rattus norvegicus) Model Luka Terbuka [Skripsi].

Fakultas Kedokteran Hewan. Universitas Brawijaya

Akita, S., A. Kozo, and H. Akiyoshi. 2013. Basic Fibroblast Growth Factor in Scarless Wound Healing. Advances in Wound Healing Care 2(2):44-48

Bliska, A.T.G., L.J. Mar, J.B Jerzy, A.R.Dale, P.R. Lawrence, A. Ahmed, and M. A. Kay.

2013. Wound Healing The Role of Growth Factor. Journal Drugs of today 39(10):787-800

Chai, H.J., H.L. Jing, and N.H. Han. 2010. Effect of Sizes and Corformations of Fish Scale Collagen Peptides on Facial Qualities and Transdermal 
Efficiency. Journal Biomed and

Biotehnnology 11(55):1-9

Corwin, E. J. 2009. Buku Saku

Patofisiologi. EGC., Jakarta. 4546.

Departemen Kesehatan Republik Indonesia. 2013. Riset Kesehatan Dasar (Riskesdas)

Laporan Nasional.

Jakarta

Fuadi, M.I., U. Elfiah, dan Musnawi. 2015. Jumlah fibroblas pada Luka bakar Derajat

II pada Tikus dengan

Pemberian Gel Ekstrak

Etanol Kakao dan Silver

sulfadiazine. Jurnal Pustaka

Kesehatan 3(2):244-248

Granick, M.S., and R.L. Gamelli. 2007. Surgical Wound Healing and Management. CRC Press., Francis. 1-15

Hendarto, K.R. 2017. Studi Terapi Kitosan Kerang Darah (Anadara granosa) Terhadap Luka Insisi Hewan Model Nosokomial Dilihat dari Ekspresi IL-1 dan Jumlah Sel Radang [Skripsi]. Fakultas Kedokteran Hewan. Universitas Brawijaya

Isrofah, Sagiran, M. Afandi. 2012. Efektifiktas Salep Ekstrak Daun Binahong (Anredera Cordifolia (Tenn) Stenis) Terhadap Proses Penyembuhan Luka Bakar Derajat 2 Termal pada Tikus Putih (Rattus norvegicus). Muhammadiyah Jurnal of Nursing 2(3):29-34

Joseph, M.M., and L.C. Kloth. 2010.

Wound Healing Evidence Based

Management. $4^{\text {th }} \mathrm{Ed}$.

Contemporary Perspectives in
Rehabilitation.

Davis

Company. Philadelphia

Hosseinimehr, S.J., K. Ghasemali, A. Mohammad, Z. Peyman, G. Maryam, and A. Amirhossein. 2010. Effect of Aloe Cream Versus Silver Sulfadiazine for Healing Burn Wounds in Rats. Acta Dermatovenerol Croat 18(1):2-7

Kamolz, L.P., M.G. Jeschke, and R. E. Horch. 2012. Handbook of Burns Volume 2:

Recontruction and Rehabilitation. Springer., New York. 52-53

Kanazawa. 2010. bFGF Regulates P13-kinase-Rac1-Jnk pathway and promotes Fibroblast Migration in Wound Heaking. PloS One. 2010: 5(8)

http://www.plosone.org/artic le/i

nfo\%3Adoi\%2F10.1371\%2Fjour nal. po ne.001 $228 . \quad[20$ November 2017]

Khazaeli, P., M. Karamouzian, S.

Rohani, B. Shadegirad, and N. Ghalekani. 2014. Effect of Minoxidil Gel on Burn Wound Healing in Rats. Iranian Journal of Pharmaceutical Research 13(01): 243-251

Kumar, B.S.A., V. Prabhakarn, K. Lakshman, R. Nandeesh, P.Subramanyam, S. Khan, D. Ranganayakalu and N.V. Khrisna. 2008.

Pharmacognostical studies of Portulaca oleracea L. Rev Bras Farmacogn. 18:4

Latifa, S.P. 2017. Pengaruh Gel Ekstrak Kolagen Kulit Ikan

Nila (Oreochromis 
niloticus) $10 \%$ terhadap

Reepitelisasi pada

Penyembuhan Luka Gingiva [Skripsi]. Fakultas Kedoktera

Gigi.Universitas Gadjah Mada

Lie, J., C. J. Kirsner. 2007. Pahophysiology of acute wound healing. Clinics in Dermatology 25(1): 9-18

Marg, G. J., L.P. Kamolz, and S. Shahrokhi. 2013. Burn Care and Treatment. A Practical Guide. Springer. Canada. 1420.

Mescher, A.L. 2016. Junqueira'r Basic Histology Text and Atlas. $4^{\text {th }}$ Edition. Mc Graw Hill Education., Indiana. 97-100 Moya, M.L., M.H Cheng, and J.J. Huang. 2010. "The effect of FGF-1 loaded alginate microbeads on neuvascularization andadipogenesia in a vascular pedicle model of adipose tissue engginering".

JournalBiomaterials 31(10):28162826

Ohara, H., S. Ichikawa, M. Akiyama, and Fujimoto. 2010. Collagen-derivad dipeptide, prolinehydroxyproline, Stimulated Cell Proliferation And Hyluruna acid Syntesis Culture Human Dermal Fibroblast. Journal Dermatol 37(4): $\quad 330-338$

Panjaitan, T.F.C. 2016. Optimasi Ekstraksi Gelatin Dari Tulang Ikan Tuna (Thunnus albacares). Jurnal Wiyata 3(1):11-16
Ravikant, M., P. Soujana, and K.

Manjunath. 2011. Heterogenecity of Fibroblast. Journal of oral and maxillofacial 15: $247-250$

The National Institute for Occupational Safety and Health. 2014. Immedietely Dangerous to Life or Health Concentration. Centers for Disease Control and Preventing(CDC) https://www.cdc.gov/niosh/i dlh.html\&hl=en-ID. $\quad$ [10 Juni 2018]

Tian, J., Kenneth, K.Y.W. Chi, K.H. Chun-Nam, L. Wing-Yiu, Y. Chiming, C. Sen, C. and Paul, K.H.T. 2008. Topical Delivery of Silver Nanoparticles Promote Wound Healing. Chemical Chem 2:129-136

Xiaoyan, Y.E., Shaokui. Z. Wenguo, Y.U. Wenglong, W.U. Xianggen, and Z. Liming. 2008. Study on Nutrient Component ant the Extracting condition or The Skin Gelatin of Tilapia. J South China Fisheris Science, 14: 55-60.

Werner, S. T. Kriegh., and H. Smola. 2007. H-KeratinocyteFibroblast Interaction in Wound Healing. Journal of Investigative Dermatology 127: 998-1008

World Health Organization. 2012. Violence and Injury Prevention (VID) http://www.who.int/violence $\underline{I}$ njuryprevention/otherinjury/ 
burns/ en/index.html.

[24 Oktober 2017]

Williams, S.L and D.P, Hopper. 2007. Understanding Medical Surgical Nursing. $3^{\text {rd }}$ Ed.

Davis

Company.,Philadelphia. 211215

Yamamoto, K., K. Igawa, K. Sugimoto, Y. Yoshizawa, K. Yanagiguchi, Y. Ikeda, S. Yamada, and H. Yahashi. 2014. Biological Safety of Fish Tilapia Collagen. Biomed Research International 10: 1-9.

Zhang, X.K. 2013. An Atlas of Histology. Springer Bussines Media., New York. 57-59

Zhang, Z., J. Wang, Y. Ding, and X.

Dai. $2015 . \quad$ Oral

Adsministration of Marine Collagen Peptides Prepared From Chum salmon Skin Enhances Cutaneus Wound Healing and Angiogenesis in Rats. Journal Sci Food Agric 91(2):2173-2179.

Zhu, H., X. Wei, K. Biann, and F. Murad. 2018. Effect of Nitric Oxide of Skin Burn Wound Healing. Journal of Burn Care and Research 29(5):1 
(C)2020. Pratiwi et al. Open access under CC BY - SA license, doi: 10.20473/mkh.v31i2.2020.52-63 Received: 23-03-2020, Accepted: 05-052020, Published online: 29-05-2020

Available at https://e-journal.unair.ac.id/MKH/index 